\title{
Facilitative Institutional Infrastructure to Optimise Productive Participation of Rural People in Local Development Processes: South Africa
}

\author{
Lennox Mzuhleli Garane \\ University of Stellenbosch, Cape Town, South Africa \\ Paul Kibuuka \\ University of South Africa (UNISA), Gauteng, South Africa
}

\begin{abstract}
Pervasive low levels of education and weak civil society activism in poor rural communities are cited as constraining factors for participatory development (PD), resulting in technical capacity for participation being skewed against the community participants. This paper highlights the outcomes of a research study that examined the applicability of the participatory development concept in conditions characterised by low levels of education and weak civil society. The research was undertaken in two rural villages in the Eastern Cape Province of South Africa, utilising both quantitative and qualitative approaches entailing interviews with 18 key informants followed by two focus group discussions each with seven participants respectively. The research found that rural communities were not aware of the government policy placing people participation at the centre of rural development interventions; and that they would not support it as they believed it was government's role to champion their development. The research also found that the government officials that lead the implementation effort of the rural development programmes did not believe that the participation policy was practical, citing capacity limitations among rural communities. The researcher recommends a moderated rural people participation process, which features creation of a facilitative institutional infrastructure to optimise productive participation of rural people in local development processes.
\end{abstract}

Keywords: participatory development, people participation, rural communities, institutional infrastructure

\section{Introduction}

Section 152(1)(e) of the Constitution of the Republic of South Africa (1996) encourages local government to involve communities and community organisations in the matters of local government highlighting that rural communities should be involved in setting the agenda for the development of their local areas, towards assuming control of their destiny. Government has implemented three rural development interventions in the past 15 years, under the expressed policy directive that rural people participation would be the main point of reference in shaping the orientation of the interventions in all respects. The main purpose for espousing

Lennox Mzuhleli Garane, MPhil. Candidate, University of Stellenbosch Business School, University of Stellenbosch, Cape Town, South Africa.

Paul Kibuuka, DPhil, Associate Professor, Bureau of Market Research, University of South Africa (UNISA), Gauteng, South Africa. 
participation is to ensure relevance to people's needs, and secure sustainability of delivered development benefits and facilities.

The first major rural development intervention, called "Integrated Sustainable Rural Development Programme" (ISRDP) was launched in 2000. The conceptualisation of the ISRDP diagnosed the constraint to realising the rural people participation objective as "weak institutional and skills base in rural areas" (Republic of South Africa, 2000). Alive to this constraint, the government adopted a policy view that the approach to implement the ISRDP would feature a "strong social mobilization" element towards building and strengthening the institutional foundation for people participation. This would be consolidated with an empowerment component to assist rural communities to participate in a manner that advances towards the ultimate goal of self-reliance. Towards the empowerment goal, the ISRDP directed preparation and implementation of a human resources (HR) development plan. The evaluation of the ISRDP revealed that no stakeholder mobilisation had taken place and no HR development programme had been implemented. It also found that government officials at the forefront of implementation considered the policy of people participation unrealistic, since rural people could not understand the technicalities involved in development processes (Everatt, Dube, \& Ntsime, 2004, p. 23).

The government launched another rural development intervention in 2009, called the "Comprehensive Rural Development Programme" (CRDP). The CRDP was also anchored on effective people participation, which would be made possible through implementation of a community empowerment programme. The evaluation of the CRDP-performed four years into implementation-found that participation by village communities was mainly occurring through representation in meetings by chiefs and ward councilors. This form of people participation was not consistent with government's commitment to embark on social mobilisation "which could have social movements for rural development as an outcome" (Republic of South Africa, 2009). The CRDP evaluation highlighted that some delivered facilities were not being utilised for the benefit for which they were conceived; pointing to a lack of ownership by the intended beneficiaries-a direct consequence of failure to ensure effective participation. Participatory development is accepted by major international development agencies as an essential component of the local development process, mainly on the strength of its proposition that it would secure enthusiastic ownership by the beneficiary communities.

The government always recognised the constraint imposed by the absence of structures for people participation in rural South Africa. The Department of Trade and Industry (DTI) highlighted in its Second Economy Strategy document that weak civil society in rural areas to represent the interests of marginalised constituencies was constraining government's effectiveness in targeting poor people's needs (Republic of South Africa, 2009). To address this constraint, the Second Economy Strategy committed government to anchor the integrated programme of rural development, land reform, and agrarian change on:

Strengthen[ing] the voice of rural South Africans, empower poor communities and build momentum behind agrarian change and land reform by supporting the self-organisation of rural people; ... and build forums and structures through which rural people can articulate their demands and interests (DTI, 2009, p. 14).

The Agri-Parks Programme is a government programme aimed at bringing about economic transformation in rural areas by improving market access for small farmers. The Agri-Parks has not been evaluated as the programme was only launched in December 2015. All available material reviewed did not clarify how the local level rural people would be mobilised to take advantage of opportunities that would flow from this intervention 
programme, targeted "to enliven rural economies" (Republic of South Africa, 2015).

This research project set out to study the applicability of the participatory development methodology in rural conditions characterised by low levels of education and weak civil society, with a view to emerge with recommendations to improve the local participatory landscape.

\section{The Theoretical Model of Participation}

The theory of participation grew out of recognition that the world's poor have suffered as a result of top-down approaches, and that all community stakeholders needed to be involved in decision-making, implementation, and benefits. The theory establishes participation as a broad concept, embedded with the component of empowerment of the "poor" development beneficiaries, to enable people to engage in an interactive process to advance their community interests. Cornwall (2008) defined the condition of interactive participation as characterised by people participating in joint analysis, development of action plans, and formation or strengthening of local institutions. Roberts (2004) defined citizen participation as the process by which members of a society share power with public officials in making substantive decisions and in taking actions related to the community. This definition envisages an effective partnership which involves power-sharing on the platform of community development activities.

\section{Brief Literature Review}

The terms "people participation", "community participation", and "citizen participation" are used interchangeably in the research, in the context of the concept of participatory development. Participatory development has gained recognition over the years as an imperative component of the development process in many industries. Herbertson, Ballesteros, Goodland, and Munilla (2009) highlighted that the International Council on Mining and Metals (ICMM), International Petroleum Industry Environmental Conservation Association (IPIECA), International Finance Corporation (IFC), and host governments of development finance projects have specific community engagement standards they require to be observed when implementing development projects affecting local communities. The development finance sector has also embraced participatory development as a key risk mitigation element, in addition to concerns for accrual of development benefits to intended beneficiaries and sustainability of financed projects.

The Asian Development Bank (ADB, 2004) introduced mainstreaming of participatory development as an integral part of its processes, to enhance the sense of ownership among beneficiaries (Ondrik, 2015). Development agencies and governments allocate substantial amounts of funds towards participation of beneficiaries in development projects; and set stringent compliance requirements (Mansuri \& Rao, 2013). Development finance interventions are initiated where private finance would not be attracted due to high risks involved, while the intervention project is considered strategic to advance national development objectives (Adjasi, 2014). Rural development interventions would be mainly financed through project finance mechanisms, hence the high necessity for ensuring realisation of maximum development benefits with funds spent. Governments, mainly in developing countries, need substantial financial resources to build critical infrastructure to support social and economic development interventions.

The Japanese International Cooperation Agency (JICA) Aid Study Committee defines participatory development "as a form of development that heightens sustainability and self-reliance and aims for the realization of social justice by improving the quality of people's participation" (JICA, 1995). Development is a 
process by which the members of a society increase their personal and institutional capacities to mobilise and manage resources to produce sustainable-and justly distributed-improvements in their quality of life, consistent with their own aspirations (Korten, 1995, as cited in Mathbor, 2008). Therefore, the element of participation in a development process is core to the definition itself, as development is about realising sustainable "improvements" that are to be "consistent with people's aspirations". According to Burns, Heywood, Taylor, Wilde, and Wilson (2004), participation means that communities are playing an active part and have a significant degree of power and influence on the development process. Community participation is essential in a local development process, to enhance social cohesion; improve democratic and service accountability; enable policy to be relevant to local communities; and to promote sustainability of development projects (Burns et al., 2004). Effective participation is characterised by processes that genuinely partner with stakeholders in the decision-making processes, so that citizens, constituents, and institutional stakeholders develop a sense of ownership which enhances the attainment of sustainable results (Ondrik, 2015). Participation of development beneficiaries permits a plurality of developmental goals to be realised as well as giving the community the self-determination it needs (Giles, 2001).

The actual participation activity is characterised by interactive exchanges of ideas, and features presentation of scenarios for evaluation towards deciding on interventions with best prospects for positive change in the lives of the poor. Cornwall (2008) submitted that interactive participation involves people participating in joint analysis, development of action plans, and formation or strengthening of local institutions. Communities in poor environments would not readily possess the requisite capacity to engage in often complex interactive exchanges over development alternatives. Norwegian Agency for Development Cooperation (NORAD, 2013) acknowledged this dilemma, positing that a critical determinant of whether participation would be productive or not is existence of functioning channels for people's participation. Such "channels" could be provided in a context of active civil society.

The critical role of civil society organisations involves "helping marginalised communities and constituencies to make their voices heard and make input into the policy process" (Greenstein, 2003, p. 64). The technical interactions on a participation platform would not be balanced, and thus unproductive-viewed from a participatory development purpose point-without rural people having competent agency. The challenge for the rural poor is that their local institutions, as vehicle for their participation, are often beset by elite control and by weak capabilities, "even when representatives of marginalised groups sit on local governance bodies, their voices rarely have clout" (Prato \& Longo, 2012). It is for this very reason that participation is more often associated with the critical issue of community empowerment.

\section{Research Methodology}

The research was conducted in two rural villages of Nyosini and Rode that are part of Ward 11 in the Umzimvubu Local Municipality, under the Alfred Nzo District Municipality (ANDM), in the Eastern Cape province of South Africa. The district has a population of about 800,000 people with an unemployment rate of about $46.1 \%$, only $16 \%$ of households have access to piped water inside the dwelling and $90.2 \%$ of the people receive an income between $1 \mathrm{R}$ and 1,600 $\mathrm{R}$ per month.

The research methodology involved both quantitative and qualitative research. The quantitative research entailed interviews with 18 key informants that were active in local civic matters in the two villages. These were followed by two focus group discussions each attended by seven participants from each of the villages 
mainly members of local based development oriented initiatives. Through questions posed under the quantitative research, the researchers were able to identify and analyse distinguishable themes. In addition, under the qualitative research, the interview guide contained eight questions that guided the focus group discussions to yield the inputs presented. In terms of the government perspective, the research relied on official published strategic documents and programme evaluation reports. These included: concept documents and implementation plans of the three major rural development intervention programmes undertaken since 2000, and the formally adopted programme evaluation reports.

In this regard, the study references the following government's flagship rural development interventions that have been implemented since 2000: ISRDP (2000), CRDP (2009), and the Agri-Parks (2015). The key informants were drawn from all developmental sectors in a typical rural community: education, women, youth, church, ward councilor, and traditional leadership. The individual respondents were not sector representatives per se, as there were no formal sector bodies in these communities. In view of this limitation, the study identified potential respondents from the ranks of individuals that were known as knowledgeable about dynamics affecting the targeted sectors.

\section{The Research Question}

The study aimed to find out from rural people themselves their appreciation of government's policy on community participation. Ancillary study dimensions included establishing rural people's understanding of the concepts of community mobilisation and empowerment; and their experiences of participation in the rural development programmes that the government had implemented since 2000. Looking beyond the study initiative, the researcher solicited ideas and suggestions from the study respondents, towards improving the rural participatory system.

\section{Key Research Findings}

\section{Socio-demographic Details of Key Respondents}

The socio-demographic profiles of the respondents (key informers) purposively selected for the quantitative part of the survey are presented in Table 1.

Table 1.1

Socio-demographic Profile of the Key Respondents

\begin{tabular}{|c|c|c|c|c|c|c|c|}
\hline $\begin{array}{l}\text { Respondent } \\
\text { No. } \\
\end{array}$ & Occupation & Gender & $\begin{array}{l}\text { Age } \\
\text { group }\end{array}$ & $\begin{array}{l}\text { Respondent } \\
\text { No. }\end{array}$ & Occupation & Gender & $\begin{array}{l}\text { Age } \\
\text { group }\end{array}$ \\
\hline 01 & Village headman & Male & $45+$ & 10 & Village chief & Female & $30-45$ \\
\hline 02 & Business & Female & $45+$ & 11 & Retired institutional specialist & Male & $45+$ \\
\hline 03 & Retired teacher & Female & $45+$ & 12 & $\begin{array}{l}\text { Development } \\
\text { activist-business }\end{array}$ & Female & $30-45$ \\
\hline 04 & Development activist-youth & Female & $30-45$ & 13 & Youth survivalist & Male & $30-45$ \\
\hline 05 & Youth activist & Male & $18-30$ & 14 & Teacher & Male & $45+$ \\
\hline 06 & Church leader & Male & $30-45$ & 15 & Youth survivalist & Male & $18-30$ \\
\hline 07 & Teacher & Female & $30-45$ & 16 & $\begin{array}{l}\text { Community development } \\
\text { worker }\end{array}$ & Female & $30-45$ \\
\hline 08 & Youth activist & Female & $30-45$ & 17 & Ward councillor & Female & $30-45$ \\
\hline 09 & Bricklayer & Male & $30-45$ & 18 & Council speaker & Male & $45+$ \\
\hline
\end{tabular}

As indicated earlier the quantitative research was followed by the qualitative research. Table 2 presents the socio-demographic details of the participants in each focus group. 


\section{The Level of Awareness on Rural People Participation Policy}

The research posed three questions to each key informant to establish their understanding of government policy statements on participation of rural people in local development initiatives. The three questions were the following:

- When the government says rural people should "set the agenda for local development in their communities", what do you understand they mean?

- When the government says rural people should "take control of their destiny", what do you understand they mean?

- When the government says rural people should be "mobilised and empowered" for development, what do you understand they mean?

Table 2

Socio-demographic Details of the Rode and Nyosini Site Focus Group Participants

\begin{tabular}{|c|c|c|c|c|c|c|c|}
\hline $\begin{array}{l}\text { Rode focus } \\
\text { group } \\
\text { participants } \\
\text { No. } \\
\end{array}$ & Occupation & Gender & Age group & $\begin{array}{l}\text { Nyosini focus } \\
\text { group } \\
\text { participants } \\
\text { No. }\end{array}$ & Occupation & Gender & Age group \\
\hline 01 & Village chief & Female & $30-45$ & 01 & Teacher & Female & $30-45$ \\
\hline 02 & $\begin{array}{l}\text { Retired institutional } \\
\text { specialist }\end{array}$ & Male & $45+$ & 02 & $\begin{array}{l}\text { Development } \\
\text { activist }\end{array}$ & Male & $30-45$ \\
\hline 03 & Teacher & Male & $45+$ & 03 & Youth activist & Female & $18-30$ \\
\hline 04 & $\begin{array}{l}\text { Development } \\
\text { activist—business }\end{array}$ & Female & $30-45$ & 04 & Bricklayer & Male & $30-45$ \\
\hline 05 & Surveyor & Male & $45+$ & 05 & Student & Female & $18-30$ \\
\hline 06 & Electrician & Male & $30-45$ & 06 & Electrician & Female & $18-30$ \\
\hline 07 & Retired chief & Male & $45+$ & 07 & Youth activist & Female & $18-30$ \\
\hline
\end{tabular}

Rural community setting agenda for own development. All respondents $(100 \%)$ at both sites did not know that the government had a policy that placed rural people at the centre of setting the agenda for their local development, intended to enable them to take control of their destiny. The qualitative statements made by the participants in this regard include: We never know where they design the projects that they come up with; anyway no community projects are done here. The recent project of Rural Development Programme (RDP) house came with the ward councillor, and we do not know the criteria they used to select beneficiaries. All we know is that the councillor acquired an RDP house before deserving poor people, yet she is earning a salary from the government.

Assuming control for own community destiny. Although the questions were posed in an open-ended manner, three distinguishable themes emerged making a quantitative analysis possible: community organisational structure as the rallying point; training of people to engage in self-help activities; and responses that showed dependency on government. Figure 1 shows that the majority (67\%) associated the meaning of the statement with people being organised around a community structure, which would lead the local development process.

The proportion of those saying that they needed training for the community to be in a position to assume control over their destiny (16\%) was almost equal to those showing dependency on government (17\%)—not imagining that rural people on their own could undertake any community development activity, citing resource and capacity constraints. The following words of mouth emerged from the informants: People need to have a 
development structure/forum where they would meet and articulate development needs to the government; government can then take the list and come back to implement the projects that address needs of the community; the municipality must meet with communities regularly—like every month to discuss progress in addressing community needs.

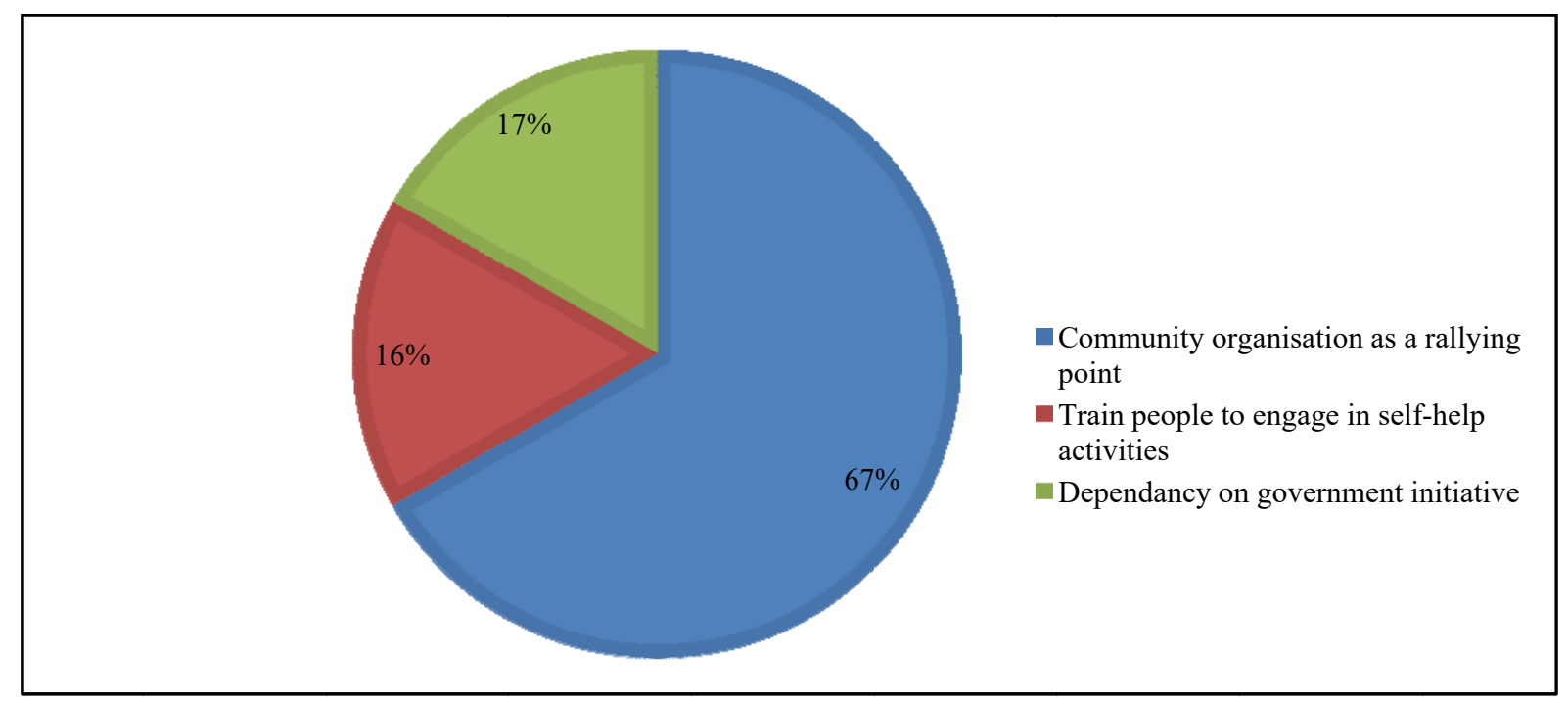

Figure 1. Community assuming control for own destiny.

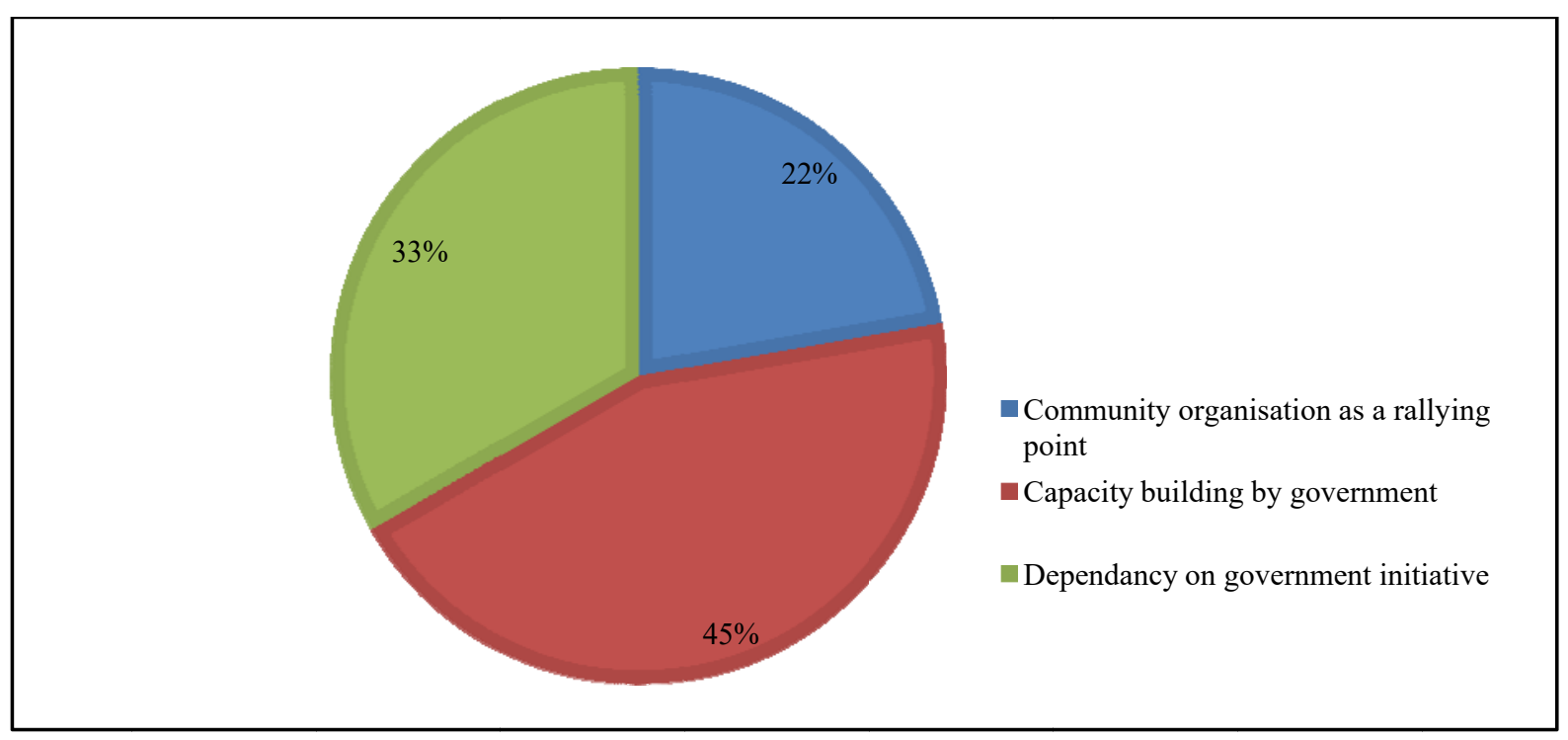

Figure 2. Community mobilisation and empowerment.

Community mobilisation and empowerment. With regard to the policy aspect of "assuming control for own destiny", similar dimensions of analysis were identifiable. However, the element of training became focused on capacity building for the community: being organised into a functional structure; technically trained on what needed to be done; and given resources and trained to manage them efficiently. As shown in Figure 2, $45 \%$ of respondents thought community mobilisation and empowerment meant that the government would capacitate communities towards self-reliance; while 33\% indicated that the government had to hand-hold the community on the process of mobilisation and empowerment. Only $22 \%$ still thought an organic process from 
within the community could set the society on the path of mobilisation and empowerment; but this group still showed an acceptance that this process needed to be co-ordinated and highlighted the need for resources to come from the government. The qualitative aspects that were shared by the respondents are that: People need knowledge; there must be government agents to help people; leave councillors out-they promote corruption; government must form a forum in the community for everybody to discuss the issues of the community; we need training - government must provide training; government should come to the people to empower us with skills for self-help; and government must implement its projects with the people-people must benefit.

\section{The Experience of Participation in Rural Development Programmes}

This component aimed to establish the experience of participation in the publicly highlighted rural development programmes that government launched during the past 15 years: ISRDP, CRDP, and Agri-Parks. The following three questions were posed:

- How was your community involved with the ISRDP?

- How was your community involved with the CRDP?

- How is your community participating in the Agri-Parks Initiative?

Respondents were asked to indicate the method or manner with which they experienced participation in the three government flagship programmes, out of the following five options:

$\diamond \quad$ Represented in project steering committee;

$\checkmark \quad$ L__ Local people were employed in projects;

$\checkmark$ A Attended meetings to discuss the project;

$\diamond \quad$ Local chief, civic structure/ward committee;

$\diamond \quad$ Do not know about the ISRDP/CRDP/Agri-Parks.

Participation in ISRDP. All (100\%) of the respondents did not know about the ISRDP.

Participation in CRDP. All (100\%) of the respondents did not know about the CRDP.

Participation in Agri-Parks. All (100\%) of the respondents did not know about the Agri-Parks Initiative.

\section{The Diagnostic of Current Participatory Practices at Local Level}

The research sought to diagnose the functionality of the current participatory practices at local level in order to explore opinions and suggestions to improve the local participatory system. To achieve this objective, the research posed three questions that were deliberately framed in an interrelated format to ensure that no system areas would be missed:

- How does your community normally learn about a development project that is proposed for your community, or that is about to be implemented in your community?

- How does your community normally liaise with the municipality regarding day-to-day service delivery and development matters?

- Are your community needs reflected in your municipality Integrated Development Plan (IDP)?

Respondents were asked to indicate which option represented the current way the community participated in local development processes:

$\checkmark \quad$ Via community leader (or ward councillor);

$\checkmark \quad$ Via the local chief (or headman);

$\checkmark \quad$ Via the civic structure (or ward committee);

$\diamond \quad$ Via a municipal official (or community development worker [CDW]); 

Unspecified source (rumours or never).

Learning about a development project planned for the community. The responses showed a uniform view of a ward councillor and ward committee as community leadership, with local chief and headman systematically subordinated on development matters. Therefore, the analysis collapsed the three options into one, leaving three areas for analysis on this question: (1) ward committee or councilor; (2) municipal official; and (3) unspecified source. It emerged that it was not frequent that there would be development projects in the two villages. As Figure 3 shows, on few occasions when community projects would materialise, $83 \%$ indicated the direct source was the ward committee member, relaying information from the ward councillor. The ward committee member would attend the community Imbizo (under the auspices of the headman), to announce the project. Respondents who learned from unspecified sources (11\%) had learned from people who would have attended the Imbizo; while the $6 \%$ that learned from municipal officials were referring to their private contacts working at the municipal offices, not an official municipal source dedicated to inform the people. The results of the qualitative research also showed that rural people were not aware of the existence of the government's policy placing people participation at the centre of rural development interventions. Participants reflected with scepticism on the policy statement that rural communities should set the agenda for development of their local areas, towards assuming control for own destiny

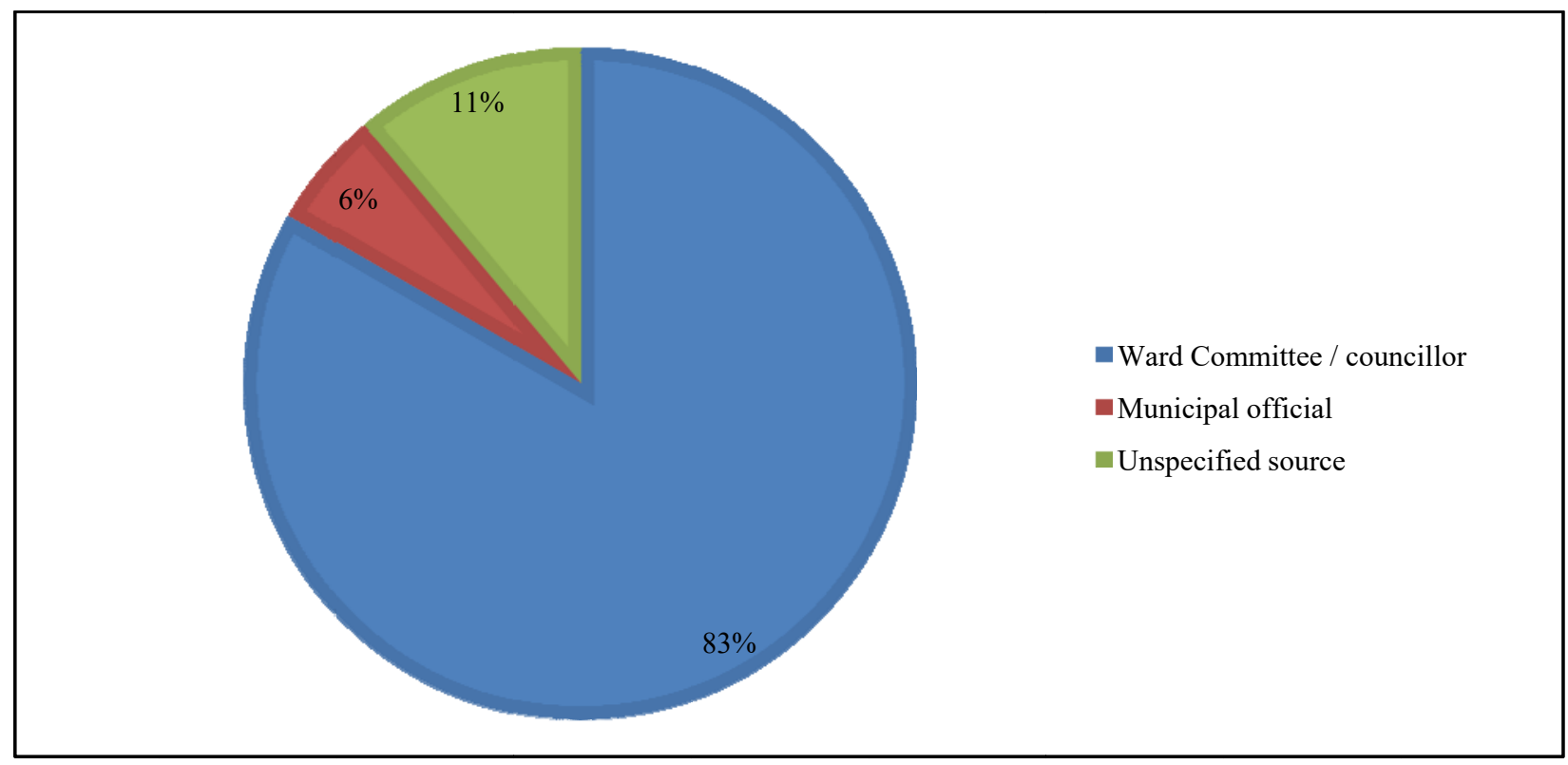

Figure 3. Learning about a development project.

Day-to-day liaison system with municipality on service delivery. The possible liaison systems posed as options were found not to be applicable, since there was no operative formal system to channel the community's concerns to the municipal administration. All respondents (100\%) said that they expected the ward councillor to be the link between the community and the municipal administration, but that system was not working.

Channelling local development needs into IDP process. All respondents $(100 \%)$ indicated that they had never been in a forum where the Integrated Development Plan (IDP) was discussed; consequently, they did not know if the local municipality IDP reflected the community's priority needs or contained any project 
earmarked for their community. The results of the qualitative research highlighted that respondents were not agreeable to the notion of rural people assuming control of their own destiny. Based on this finding, the researcher concluded that rural communities in South Africa are not likely (in the foreseeable future) to be in a position to set their own local development agenda, due to constraints, including lack of basic confidence as a result of their disempowering poverty conditions, which have rendered them entirely dependent on government

\section{The Suggestions to Improve the Participatory Institutional System}

In order to formulate informed system improvement recommendations, the researcher solicited suggestions from the research participants on the following system areas:

- Formal channel to the government system for incorporation of people's inputs into development plans and programmes targeted for their community;

- Agency for representation of community views to the government system, and a report back mechanism to consolidate the people's mandate;

- Sustaining government or community links over service delivery and development issues.

With regard to this section, four themes emerged which make a quantitative analysis of the responses possible, despite the fact that the questions were open-ended. The themes that emerged were: (1) traditional authority; (2) ward councillor or committee; (3) local development structure; and (4) government-sponsored mechanism. Figure 4 shows that the majority (45\%) of respondents favoured a government-sponsored local participatory system, implemented by a competent agency. The qualitative statements advanced by the informants in this respect included that: Government should have an ICT-based system of communicating to people in this community-through to the councillor; if government uses an agency, it should ensure service delivery and engage the people accordingly; the agency of government must bring people into a collective, if rural people are going to change their lives.

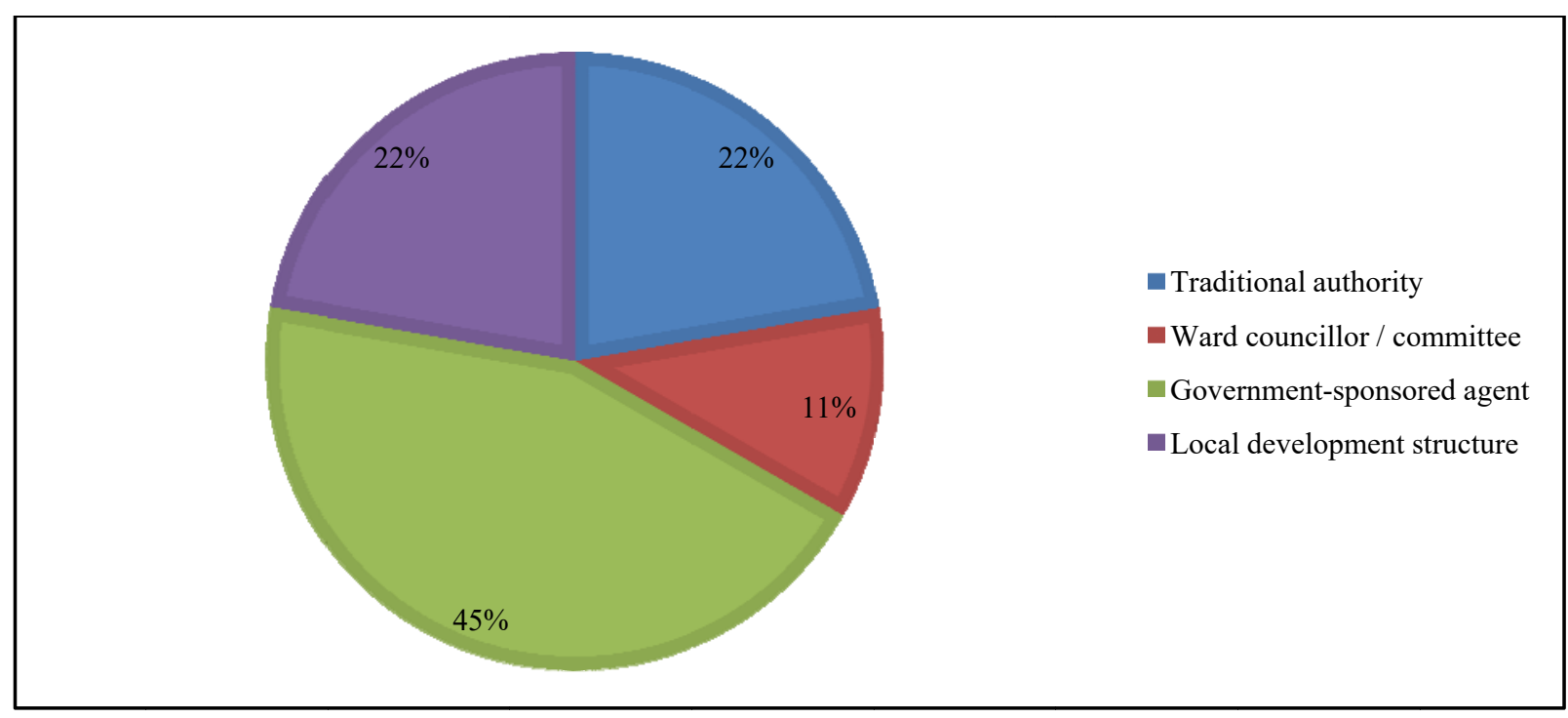

Figure 4. Suggestions for system improvement

\section{Towards a Structure-Based Model of Participation}

Uphoff (1993) narrated a comparative study of rural development interventions in 16 countries of Asia, which set to assess different modalities of PD application in practice and value realised. The study concluded 
that countries which had the best linkages between central government and rural communities through local institutions performed better in agriculture and social indicators, compared to contexts where this linkage did not exist. Mobilising rural communities into effective organisations can also result in higher level development benefits, including promoting economic and social development and contributing to democratisation of the economy, society and local politics (Uphoff, 1993).

Heimans (2002) posited that an institutional platform could serve as a vehicle of citizen empowerment, improve social equity outcomes for the disadvantaged groups, and thus catalyse poverty reduction. It all comes back to the crux of this proposed research study: the need for a credible and capable people participation agency, to harness people's inputs and channel them to influence the development process to benefit the local community. In the context of poverty reduction work, Schneider (1999, p. 13) described "empowerment" as "the gaining of strength in the various ways necessary to move out of poverty"-further submitting that empowerment of the poor is an intrinsic and pervasive objective in the participatory development process. Consistent with the South African government policy on participatory development, Schneider $(1999$, p. 20) stated:

Ideally, to secure continuous "business-like" influence and build up mutual confidence, and to avoid wasting energy and possibly sympathy in acrimonious fighting with the bureaucracy, "partnership bodies" should be built through which organisations of the poor and the public sector can cooperate on a regular basis and thus learn to "mainstream" participatory governance.

This research offers an alternative approach to achieve effective rural people participation in local development processes-the moderated rural people participation process (MRPPP). The model features creation and consolidation of a sustainable rural civil society system, necessary to improve participatory local governance, development, and democracy in a rural locality.

\section{Moderated Rural People Participation Process-The Concept}

The concept is inspired by the philosophy of repairing civil society as a strategy towards creating an environment for people participation (Mansuri \& Rao, 2013). Rural people do not have an agency to assert themselves on a local development process due to non-existent civil society capacity in rural areas. This research observed that people in rural villages did not enjoy the basic right of having a local government that reached out to them. They were effectively locked-out. The desired rural community participation, to set the agenda for their local development towards assuming control for their destiny, was not feasible under the present set of conditions in rural areas. The caution in the CRDP evaluation report (Republic of South Africa, 2013) that there was a real risk to value for money being not realised, should be viewed as an alarm bell. It is against this backdrop that the moderated rural people participation process was conceived.

\section{MRPPP concept overview.}

- The model is designed to operate on a platform of an institution-building structural base (shown on next page), to ensure sustainability of the intervention. It features creation and consolidation of a sustainable rural civil society system, necessary to improve participatory local governance, development, and democracy.

- The structures that shall serve as platforms to discuss people's inputs into local development processes shall be facilitated by field community workers (FCWs).

- The model is anchored on moderation by a qualified social services professional, with organisational development and social facilitation skills, who shall serve as the overall process moderator (PM) in a municipality. 
FACILITATIVE INSTITUTIONAL INFRASTRUCTURE

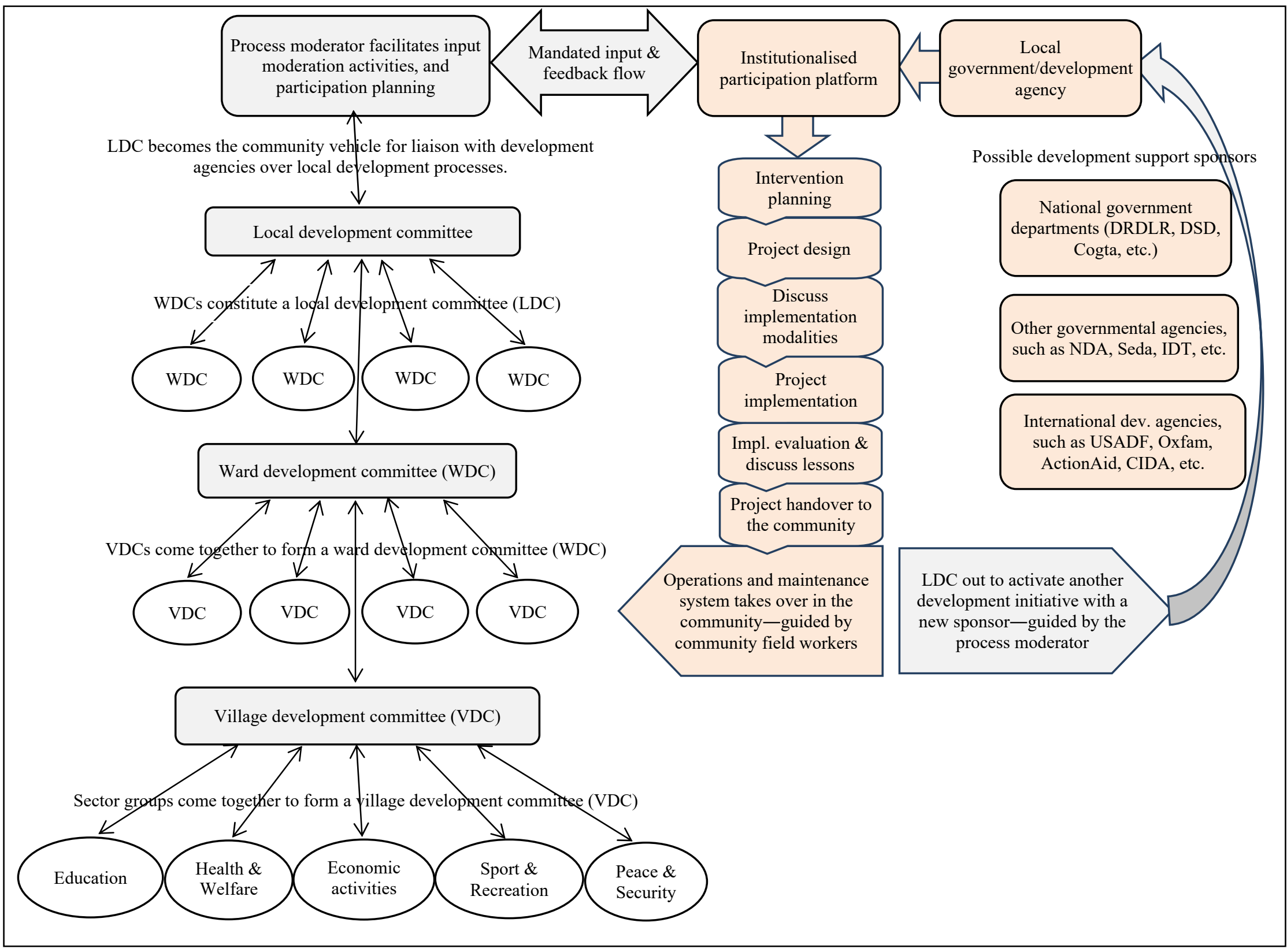


- The PM shall be assisted by FCWs, to be employed by the local municipality under the community development worker (CDW) programme, but shall be assigned field organising assignments by the process moderator.

- FCWs shall be trained in all critical skills necessary towards achieving the objectives of this initiative-before deployment.

Processing rural people inputs into a local development process. Scenario, using the municipal IDP process as an example: People are required to express their development needs and priorities to the local municipality IDP process. The following activities will unfold, leading to realisation of substantive submissions of the people into the actual plan:

- The PM, accompanied by the chairperson and secretary of the local development committee (LDC), meets with top level management of the municipality, both political and administration components, to obtain full clarification of expectations from the development agency side.

- The PM would convene a full meeting of the LDC together with all CFWs, to discuss and establish a common understanding of the facilitation work that needs to be conducted to obtain inputs from the people in a structured manner, to ensure that the IDP would reflect the community's needs and priorities.

- LDC members convene meetings with their respective ward development committees (WDCs) in their wards; embedded CFWs play a facilitative role in support of chair and secretary.

- WDC members break down into their village development committees (VDCs).

- Sector representatives in VDCs go to their sectors to solicit original ideas pertaining to respective sector needs and other cross-cutting areas.

- Collection of original raw data for submission to the development process starts at the sector level within the village, and processed upstream through all people structures.

- Levels upstream screen, align, prioritise, and balance priorities-taking into account competing interests of villages and wards.

- The PM eventually compiles a package of local development needs and priorities into a formal local civil society submission to the IDP relevant structure.

- The PM attends the meetings of the IDP with the whole LDC committee.

- Substantive rural people participation is realised into the local municipality IDP.

\section{Operational modalities of an MRPPP system.}

- The system assumes that the municipality shall be an effective entry point for all development initiatives into the community; based on the fact that all interventions would have been coming to support the approved Integrated Development Plan (IDP) of the local municipality.

- The municipality has to have a dedicated office to liaise with the community (represented by the LDC-with process moderator embedded) on development matters, with clear performance imperatives.

- The moderation level would be considering and consolidating/harmonising various inputs/proposals emanating from all the wards in a municipality.

- The moderation activities shall feature the process moderator assisting the LDC to:

- Work through what is feasible and what is not;

- Discuss and formulate feasible development proposals;

- Discuss negotiation strategies, and agree on an approach; 
- Coach the LDC members on how to present their case at the negotiation table;

- Plan the feedback to the community.

\section{Development benefits.}

- Rural people participation would have been effectively institutionalised, through a sustainable facilitative and productive structural system;

- The moderation component shall optimise the productivity of the institutional infrastructure, serving to anchor a responsive governance architecture in rural municipalities in South Africa;

- Community field workers (CFWs) are going to be recruited from the pool of unemployed graduates, thus contributing to rural youth employment, while building a contingent of rural development professionals at the same time;

- This model will attack the current state of despair in rural areas, and convert it to enthusiasm and productive energy for self-help activities;

- This intervention will serve as a vehicle to organise skills training to help rural people start their own self-help activities, thus enable government interventions to achieve the goal of poverty reduction in rural villages.

\section{Conclusion and Recommendation}

The paper is based on both quantitative and qualitative research conducted in a South African rural setting. The research referenced three major rural development programmes implemented in the past 15 years. The research concluded that rural communities were not likely to be in a position to set their own local development agenda due to constraints, including lack of basic confidence as a result of their disempowering poverty conditions, which has rendered them entirely dependent on government.

The paper pointed out that while PD is conceptually valuable, it has not been successfully applied in practice; the writer agues the situation calls for reorientation of the methodology in practice. Further to this assessment, the researcher presented his theoretical analysis of a typical participation platform, to indicate the impracticality of $\mathrm{PD}$ in an unassisted form, due to constraints prevalent in poverty contexts.

The paper proposes a situational turn-around "moderated rural people participation process", which features creation and consolidation of a sustainable rural civil society system, necessary to improve participatory local governance, development, and democracy in a rural locality. However, given that the study utilised a non-probability purposive sampling approach, the results cannot be extrapolated with certainty on the entire district or rural areas in general. The two sites possess social and institutional characteristics that are prevalent in rural areas across South Africa; therefore, the findings and recommendations would contribute to national policy debate on rural people participation development processes.

\section{References}

Adjasi, C. (2014). Financing Africa's growth: The role of development finance. Development Finance in Africa Agenda No.2. Retrieved from http://www.usb.ac.za.

Asian Development Bank (ADB). (2004). Effectiveness of participatory approaches: Do the new approaches offer an effective solution to the conventional problems in rural development projects? Operations Evaluation Department, Asian Development Bank. Retrieved from https://www.adb.org/sites/default/files/evaluation-document/35012/files/ses-effectiveness.pdf

Barron, P., Diprose, R., \& Woolcock, M. (2007). Local conflict and development projects in Indonesia: Part of the problem or part of the solution? WB Policy Research Paper 4212. Retrieved from http://documents.worldbank.org/curated/en/491351468285607493/pdf/wps4212.pdf 
Bartle, P. (2008). Human factor and community empowerment. Review of Human Factor Studies, 14(1), xx-xx. Retrieved July 25, 2017, from http://cec.vcn.bc.ca/cmp/modules/emp-ce.htm

Burns, D., Heywood, F., Taylor, M., Wilde, P., \& Wilson, M. (2004). Making community participation meaningful: A handbook for development and assessment. Bristol BS8 1QU, UK: The Policy Press for Joseph Rowntree Foundation.

Chu, J., Young, K., \& Phiri, D. (2015). Large-scale land acquisitions, displacement and resettlement in Zambia. Policy Brief No 41/01, Institute for Poverty, Land and Agrarian Studies, University of the Western Cape, South Africa.

Claridge, T. (2004). Designing social capital sensitive participation methodologies. Retrieved June 27, 2017, from http://www.socialcapitalresearch.com/wp-content/uploads/2013/01/Social

Cook, J. B. (1994). Community development theory. Department of Community Development, University of Missouri Extension. Retrieved June 28, 2016, from http://extension.missouri.edu/p/MP568

Cornwall, A. (2008). Unpacking "Participation": Models, meanings and practices. Community Development Journal, 43(3), 269-283.

Everatt, D., Dube, N., \& Ntsime, M. (2004). Integrated sustainable rural development programme. Department of Land Affairs, Pretoria, Republic of South Africa. https://www.researchgate.net/publication/308801993_Integrated_Sustainable_Rural_Development_Programme_ISRDP_nod al_report

Forrester, S. (2011). A guide community mobilisation for empowerment moldova. Retrieved August 15, 2017, from http://docplayer.net/21289300-A-guide-community-mobilisation-for-empowerment-moldova.html

Foti, J., \& de Silva, L. (2010). A seat at the table: Including the poor in decisions for development and environment. World Resource Institute, Washington, DC. Retrieved May 7, 207, from http://pdf.wri.org/a_seat_at_the_table.pdf

Ghaus-Pasha, A. (2005). Role of civil society organisations in governance. Paper presented at The 6th Global Forum on Reinventing Government towards Participatory and Transparent Governance, 24-27 May, Seoul, Republic of Korea.

Giles, M. (2001). Participatory development. In V. Desai and R. B. Potter, (Eds.), The Arnold companion to development studies (pp. 49-54, Part III). London: Hodder.

Greenstein, R. (2003). State, civil society and the reconfiguration of power in post-apartheid South Africa. Pretoria.

Hall, R., \& Kepe, T. (2017). Elite capture and state neglect: New evidence on South Africa's land reform. Review of African Political Economy, 44(151), 122-130. doi:10.1080/03056244.2017.1288615

Heimans, J. (2002). Strengthening participation in public expenditure management: Policy recommendations for key stakeholders. $\begin{array}{llll}\text { Policy } & \text { Brief } & \text { No.22. } & \text { Retrieved }\end{array}$ https://www.internationalbudget.org/wp-content/uploads/Strengthening-Participation-in-Public-Expenditure-Management-Po licy-Recommendations-for-Key-Stakeholders.pdf

Herbertson, K., Ballesteros, A. R., Goodland, R., \& Munilla, I. (2009). Breaking ground: Engaging communities in extractive and infrastructure projects. Washington: World Resource Institute.

Holland, J., Thirkell, A., Trepanier, E., \& Earle, L. (2009). Measuring change and results in voice and accountability work. Working Paper 34. Retrieved from https:/www.oecd.org/derec/unitedkingdom/44463612.pdf

Japan International Cooperation Agency (JICA). (1995). Participatory development and good governance: Report of the aid study committee. $\quad$ Retrieved from https://www.jica.go.jp/jica-ri/IFIC_and_JBICI-Studies/english/publications/reports/study/topical/part/part_1.html

Lord, J., \& Hutchison, P. (1993). The process of empowerment: Implications for theory and practice. Canadian Journal of Community Mental Health, 12(1), 5-22.

Mansuri, G., \& Rao, V. (2013). Localising development-Does participation work? Washington: World Bank.

Mathbor, G. M. (2008). Effective community participation in coastal development. New Jersey: Monmouth University.

MercyCorps. (n.d.). Guide to community mobilization programming. Retrieved July 25, 2017, from http://www.mercycorps.org

Mudova, T. (2015). Understanding land acquisitions in Namibia's communal land: Impacts and policy implications. Policy Brief No. 39/01, Institute for Poverty, Land and Agrarian Studies, University of the Western Cape, South Africa. Retrieved from http://repository.uwc.ac.za/xmlui/bitstream/handle/10566/4294/pb_39_understanding_land_acquisitions_namibia_communal land_2015.pdf?sequence $=1 \&$ isAllowed $=\mathrm{y}$

Naku, D. W. C., \& Afrane, S. (2013). Local community development and participatory planning approach: A review of theory and practice. Current Research Journal of Social Sciences, 5(5), 185-191.

Norwegian Agency for Development Cooperation (NORAD). (2013). A framework for analysing participation in development. Report 1/2013. Retrieved from https://www.oecd.org/derec/norway/NORWAY_A_FrameworkforAnalysingParticipationDevelopment.pdf 
Ondrik, R. S. (2015). Participatory approaches to the National Development Planning. Asian Development Bank. Retrieved June 27, 2016, from http://siteresources.worldbank.org/INTEASTASIAPACIFIC/Resources/226262-1143156545724/Brief_ADB.pdf

Prato, B., \& Longo, R. (2012). Empowerment of poor rural people through initiatives in agriculture and natural resources management. Promoting Pro-Poor Growth: The Role of Empowerment. Retrieved from $\mathrm{http} / /$ www.oecd.org/investment/stats/50157503.pdf

Republic of South Africa. (2000). Integrated Sustainable Rural Development Programme (ISRDP). Pretoria: Department of Rural Development and Land Reform (DRDLR).

Republic of South Africa. (2009). Comprehensive rural development programme (CRDP). Pretoria: Department of Rural Development and Land Reform (DRDLR).

Republic of South Africa. (2009). Second economy strategy: Addressing inequality and economic marginalisation. Second Economy Project, Trade and Industrial Policy Strategies, Department of Trade and Industry (DTI). Retrieved from http://www.tips.org.za/files/Second_Economy_Strategy_Framework_Jan_09_0.pdf

Republic of South Africa. (2013). Implementation evaluation of the CRDP. Pretoria: Department of Rural Development and Land Reform (DRDLR).

Republic of South Africa. (2015). The rural economy transformation model: One district, one Agri-Park/every municipality a CRDP site. Pretoria: Department of Rural Development and Land Reform (DRDLR).

Roberts, N. (2004). Public deliberation in an age of citizen participation. American Review of Public Administration, 34(4), 315-353.

Sadan, E. (1997). Empowerment and community planning: Theory and practice of people-focused social solutions. (R. Flantz, Trans.). Tel Aviv: Hakibbutz Hameuchad Publishers.

Schneider, H. (1999). Participatory governance: The missing link for poverty reduction. Paris: OECD Publishing. Retrieved June 27, 2016, from http://dx.doi.org/10.1787/888041015581

The Constitution of the Republic of South Africa. (1996). Act 108 of 1996. Retrieved from https://www.gov.za/sites/default/files/images/a108-96.pdf

Uphoff, N. (1993). Grassroots organisations and NGOs in rural development: Opportunities with diminishing states and expanding markets. World Development, 21(4), 607-622.

Wilcox, D. (1994). Community participation and empowerment: Putting theory into practice. RRA Notes, (21), 78-83. Retrieved June 27, 2016, from http://pubs.iied.org/pdfs/G01549.pdf

Wolff, T. J. (1993). Coalition building: Is this really empowerment? Paper presented at The American Public Health Association's Annual Meeting, 25 October, San Francisco, California. 


\section{Appendices}

Research Questionnaire: Questions for Community Sector Respondents

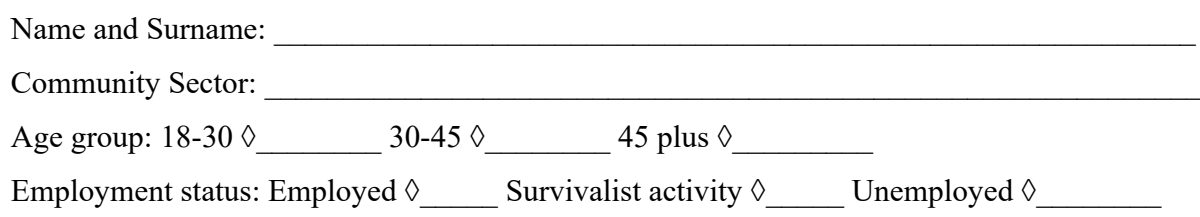

The aim of these questions is to assess the level of awareness about the government policy stance on rural communities "setting the local agenda for development" and "taking control of their destinies"; level of participation in current government rural development initiatives; and current institutional system for rural people participation.

Section 1-Policy awareness

(1) When government says rural people should "set the agenda for local development in their communities", what do you understand they mean?

(2) When government says rural people should "take control of their destinies", what do you understand they mean?

(3) When government says rural people should be "mobilised and empowered" for development, what do you understand they mean?

Section 2-Level of participation in current initiatives

How was your community involved with the ISRDP?

$\diamond \quad$ Represented in project steering committee;

$\diamond \quad$ L__ Local people were employed in ISRDP projects;

$\diamond \quad$ Attended meetings to discuss the project;

$\diamond \quad$ L__ Local chief, civic structure/ward committee;

$\diamond \quad$ Do not know about the ISRDP.

How was your community involved with the CRDP?

$\diamond \quad$ Represented in project steering committee;

$\checkmark \quad$ L__ Local people were employed in CRDP projects;

$\diamond \quad$ Attended meetings to discuss the project;

$\diamond \quad$ Local chief, civic structure/ward committee;

$\diamond \quad$ Do not know about the CRDP.

How is your community participating from the Agri-Parks Initiative?

$\diamond \quad$ Represented in project steering committee;

$\diamond \quad$ L__ Local people were employed in Agri-Parks Initiative;

$\diamond \quad$ Attended meetings to discuss Agri-Parks Initiative; 

Do not know about the Agri-Parks Initiative.

Section 3-Current participatory institutional systems

How does your community normally learn about a development project that is proposed for your community, or that is about to be implemented in your community?

$\checkmark \quad$ Via community leader (or ward councillor);

$\diamond \quad$ Via the local chief (or headman);

$\checkmark \quad$ Via the civic structure (or ward committee);

$\diamond \quad$ Via a municipal official (or CDW);

$\diamond \quad$ Unspecified source (rumours or never).

How does the community inform the municipality of its development needs?

$\diamond \quad$ Via community leader (or ward councillor);

$\checkmark \quad$ Via the local chief (or headman);

$\diamond \quad$ Via the civic structure (or ward committee);

$\diamond \quad$ Via a municipal official (or CDW);

$\diamond \quad$ Unspecified source (rumours or never).

How does your community normally liaise with the municipality regarding day-day service delivery and development matters?

$\diamond \quad$ Via community leader (or ward councillor);

$\diamond \quad$ Via the local chief (or headman);

$\diamond \quad$ Via the civic structure (or ward committee);

$\diamond \quad$ Via a municipal official (or CDW);

$\checkmark \quad$ Unspecified source (rumours or never).

Are your community needs well reflected in your local municipality Integrated Development Plan (IDP)?

$\diamond \quad$ Represented in IDP representative structure;

$\diamond \quad$ There was a public meeting to solicit community views;

$\diamond \quad$ Attended meetings organised by the ward councillor;

$\diamond \quad$ Local chief, civic structure/ward committee;

$\diamond \quad$ Never heard of a local municipality Integrated Development Plan.

The next questions aim to establish suggestions/ideas and principles that would anchor any proposed institutional participatory system, from a practical and functional viewpoint in the context of a rural setting. 
How could community inputs be formally channelled to the government system for incorporation into plans and programmes targeted for rural development? Who would you trust as reliable agency to channel and represent your views as a community?

How this suggested "reliable agency" should draw people's views to acquire the mandate for representing the community? Suggest a feedback system:

What system would you like to be put in place to ensure continuous purposeful communication with government authorities on general service delivery and development issues in your location? Suggest a desirable scenario:

What are the service delivery priorities for this community? Mention 3.

\section{Focus Group Discussion Guide}

What would you like to be done to ensure that the community know full details of a proposed project, and influence its content and implementation process?

What should happen, or be in place and operative, to ensure regular meetings to discuss local development needs to be submitted to the municipality?

What do you think would make the community feel they are seriously informing the development process in your area?

If a development agency builds a facility for use by the community (like a community centre) and hands it over to the community, what would be the best way to make it serve the interests of the whole community equitably? Suggest a management system that the community would view as fair and equitable.

Who do you think should have the responsibility to bring the community together to generate ideas about development needs of the community?

If the three service delivery priorities listed could be attended, how would the community change? Present a picture-a scenario.

If you do not know much about the government's rural development programmes, how should government inform now and about the future programmes?

How should the "reliable agency" feedback system actually work? 